\title{
ГОРМОНАЛЬНА РЕГУЛЯЦІЯ Са-Р ОБМІНУ У ПАЦІЄНТІВ ІЗ ХРОНІЧНОЮ ХВОРОБОЮ НИРОК ТА ТЕРАПЕВТИЧНІ ПІДХОДИ ДО КОРЕКЦІї
}

\author{
МОЙСЕЄНКО В.О., МЕДВЕДЄВ Т.М.
}

\author{
Національний медичний університет імені О.О. Богомольця \\ Київ, Україна
}

Резюме

\begin{abstract}
Вступ. Однією з найбільш частих і важких проблем, що виникають при лікуванні діалізних хворих, є корекція фосфорно-кальцієвого обміну. При хронічній нирковій недостатності порушуються всі ланки фосфорно-кальцієвого обміну. При зниженні швидкості клубочкової фільтрації (ШКФ) нижче 60 мл/хв /1,73 м² зменшується фільтрація фосфору і підвищується його сироваткова концентрація, що викликає підвищення секреції паратиреоїдного гормону (ПТГ).

Мета. Узагальнити відомості про роль гормональної регуляції фосфорно-кальцієвого обміну в патогенезі розвитку хронічної хвороби нирок та серцево-судинних захворювань, що їі супроводжують, і проаналізувати основні терапевтичні підходи для корекції цих порушень.
\end{abstract}

Матеріали та методи. Бібліографічний - проведено теоретичний аналіз та здійснено узагальнення даних літератури, проаналізовано фактичний вміст. При дослідженні використано анкетно-опитувальний метод, а також - опис, аналіз, реферування. Результати та їх обговорення. ПТГ продукується головними клітинами паращитоподібних залоз (ПЩЗ). Концентрація Са2 + в сироватці крові $є$ основним модулятором секреції ПТГ [2]. Стимуляція кальцій-чутливих рецепторів (КЧР) ПЩЗ через каскад реакцій призводить в підсумку до пригнічення секреції ПТГ. Додатковим стимулом збільшення секреції ПТГ $є$ гіперфосфатемія. ПТГ має наступні фізіологічні ефекти: стимулює резорбцію кальцію з кісткової тканини, реабсорбцію кальцію в ниркових канальцях. Вітамін $D\left(D_{3}\right.$ i $\left.D_{2}\right)$ в асоціації з вітамін D-зв'язуючим білком переноситься в печінку, де гідроксилюється з утворенням 25(OH)D або кальцидіолу (KD), який в подальшому зазнає $1 \alpha$-гідроксилювання в ниркових канальцях, перетворюючись в активну форму вітаміну D - кальцитріол (KT) або D-гормон. Білок Клото є трансмембранним протеїном, який крім інших ефектів, забезпечує певною мірою чутливість організму до інсуліну і уповільнює процес старіння в дослідах на тваринах. FGF23 має фосфатурічний ефект, стимулює секрецію ПТГ і гальмує $1 \alpha$-гідроксилазну активність нирок, призводячи до зниження синтезу КТ і його рівня в сироватці крові. Висновки. Підвищення рівнів FGF23 і ПТГ є відповідальним за несприятливі ефекти надмірного вмісту фосфатів, але інгібування цих компенсаційних механізмів клінічно неможливо, тому що це призводить до небезпечних змін в мінеральному обміні. При цьому, профілактика кардіоваскулярних ускладнень у осіб з порушеннями в системі FGF23/Klotho повинна включати корекцію вмісту фосфатів, так як їх атерогенну роль продемонстровано, а спроби зменшити абсорбцію фосфатів з використанням тільки фосфат-біндерів можуть результувати збільшенням абсорбції фосфатів в той час, коли фосфат-біндери не присутні в порожнині кишківника. Можливим терапевтичним підходом також $є$ дієтичний контроль у таких пацієнтів за рівнем Са, Р та вітаміну D з блокадою кишкового активного перенесення фосфатів для зниження дієтичної фосфатної абсорбції.

Ключові слова: фосфорно-кальцієвий обмін, хронічна хвороба нирок, серцево-судинні розлади.

Вступ. В останні роки в усьому світі реєструється стійке зростання числа хворих, які отримують лікування програмним гемодіалізом. Це пов'язано зі збільшенням тривалості життя пацієнтів, більшою доступністю гемодіалізу і з переглядом багатьох критеріїв, що регламентують відбір хворих для проведення програмного ге- модіалізу [5]. Однією з найбільш частих і важких проблем, що виникають при лікуванні діалізних хворих, $є$ корекція фосфорно-кальцієвого обміну.

При хронічній нирковій недостатності порушуються всі ланки фосфорно-кальцієвого обміну. При зниженні швидкості клубочкової фільтрації (ШКФ) нижче 60 мл /хв /1,73 м² зменшу- 
ється фільтрація фосфору і підвищується його сироваткова концентрація, що викликає підвищення секреції паратиреоїдного гормону (ПТГ). Паратиреоїдний гормон пригнічує реабсорбцію фосфору, таким чином нормалізуючи його рівень в сироватці крові, але при падінні ШКФ нижче 30 мл/хв /1,73 м² цей механізм підтримки нормальної сироваткової концентрації фосфору стає недостатньо ефективним і розвивається стійка гіперфосфатемія, що стимулює посилену секрецію ПТГ. При гіперфосфатемії знижуються продукція і вміст в сироватці крові кальцитріолу. Дефіцит кальцитріолу викликає порушення всмоктування кальцію в тонкому кишківнику і розвиток гіпокальціємії. При гіпокальціємії, персистуючої протягом місяців, розвивається гіперплазія паращитоподібних залоз (ПЩЗ), яка обумовлює надлишкову продукцію і секрецію ПТГ, що поряд з гіперфосфатемією $є$ проявом вторинного гіперпаратиреозу (ВГПТ). Гіпокальціємія, дефіцит вітаміну D і гіперфосфатемія найважливіші чинники, відповідальні за гіперплазію паращитоподібних залоз.

Вторинний гіперпаратиреоз, що розвивається у пацієнтів з хронічною нирковою недостатністю, сприяє розвитку фіброзно-кістозної остеодистрофії, яка характеризується високою швидкістю кісткового ремоделювання, зниженням мінералізації кісток, формуванням кісткових кіст, остеосклерозом і остеомаляцією. Основними клінічними симптомами остеодистрофії є болі в кістках і м'язова слабкість. Встановлено, що гіперпаратиреоз грає важливу роль не тільки в розвитку змін скелета, але і в патогенезі кальцифікації судин і клапанів серця, гіпертрофії лівого шлуночка, дисфункції імунної системи, анемії.

В моніторинг параметрів фосфорно-кальцієвого обміну у діалізних хворих входить визначення в сироватці крові кальцію і фосфору, лужної фосфатази, ПТГ. У хворих, які отримують лікування препаратами, що впливають на фосфорно-кальцієвий обмін, дослідження необхідно проводити частіше. Встановлено, що зміни деяких ключових параметрів фосфорно-кальцієвого обміну $є$ факторами ризику смертності у діалізних хворих [6].

Основними гормонами, що регулюють Са-P обмін є паратиреотропний гормон (ПТГ), кальцитріол (КТ) і кальцитонін. Значимість останнього у людей, на відміну від тварин, не встановлено, тому що він не має істотного впливу на регуляцію кальцієвого гомеостазу. Також, нещодавно виявлені нові гормони: FGF23 і Клото, котрі мають ключову роль в регуляції Са-Р гомеостазу [1].

Мета. Узагальнити відомості про роль гормональної регуляції фосфорно-кальцієвого обміну в патогенезі розвитку хронічної хвороби нирок та серцево-судинних захворювань, що ії супро- воджують, і проаналізувати основні терапевтичні підходи для корекції цих порушень.

Матеріали і методи. Бібліографічний - проведено теоретичний аналіз та здійснено узагальнення даних літератури, проаналізовано фактичний вміст. При дослідженні використано анкетно-опитувальний метод, а також - опис, аналіз, реферування.

\section{ГОРМОНАЛЬНА РЕГУЛЯЦІЯ ФОСФОРНО- КАЛЬЦІЄВОГО ОБМІНУ У ХВОРИХ НА ХРОНІЧНУ ХВОРОБУ НИРОК}

ПТГ - це лінійний поліпептид, що складається з 84 амінокислотних залишків з молекулярною масою близько 9500 Да. Він продукується головними клітинами паращитоподібних залоз (ПЩЗ). Концентрація Са2 + в сироватці крові є основним модулятором секреції ПТГ [2]. Стимуляція кальцій-чутливих рецепторів (КЧР) ПЩЗ через каскад реакцій призводить в підсумку до пригнічення секреції ПТГ. Додатковим стимулом збільшення секреції ПТГ $є$ гіперфосфатемія. ПТГ має наступні фізіологічні ефекти: стимулює резорбцію кальцію з кісткової тканини, реабсорбцію кальцію в ниркових канальцях, гідроксилювання 25(OH)D в 1,25(OH)2D в нирках, екскрецію фосфату нирками. ПЩЗ швидко реагують (протягом хвилин) на зміни концентрації Са2 + сироватки крові.

1,25(OH)2 вітамін D, кальцитріол (KT) або D-гормон. 3 біологічної точки зору, КТ $€$ повноцінним стероїдним гормоном, так як синтезується в організмі і володіє високоспецифічним рецептором вітаміну D (РВД) [27]. Більша частина вітаміну D (ВД) (90-95\%) утворюється в шкірі під впливом ультрафіолетового опромінення, менша частина надходить з тваринною (вітамін $\mathrm{D}_{3}$ ) або рослинною $\left(D_{2}\right)$ їжею. Запаси ВД зберігаються в основному в печінці з періодом напіврозпаду приблизно 14 днів. При всмоктуванні великої кількості ВД його надлишок зберігається в основному в жировій тканині. Далі вітамін $D\left(D_{3}\right.$ i $\left.D_{2}\right)$ в асоціації з вітамін D-зв'язуючим білком переноситься в печінку, де гідроксилюється з утворенням 25(OH)D або кальцидіолу (КД), який в подальшому зазнає $1 \alpha$-гідроксилювання в ниркових канальцях, перетворюючись в активну форму вітаміну D - кальцитріол (KT) або D-гормон, який діє через РВД. Основні ефекти D-гормону полягають в підвищенні всмоктування Са і фосфату $\mathrm{P}$ в тонкій кишці. Значно більш слабкий вплив він має на нирки, що приводить до посилення реабсорбції Ca i P. Крім того, D-гормон гальмує секрецію ПТГ. Він також сприяє мінералізації кісток і резорбції з них Са. Слід відзначити, що КД грає не менш важливу роль, ніж КТ, так як багато тканин мають власну $1 \alpha$-гідроксилазну активність і здатні перетворювати КД в КТ для власних потреб (аутокринна функція ВД).

FGF23 являє собою протеїн з молекулярною масою 30 кДа, який розщеплюється ензимом 
проконвертазного типу на 2 менших фрагмента: 18 кДа (аміно-фрагмент) і 12 кДа (карбокси-фрагмент) [Stubbs J, Liu S, Quarles LD. Role of fibroblast growth factor 23 in phosphate homeostasis and pathogenesis of disordered mineral metabolism in chronic kidney disease. Semin Dial 2007; 20 (4): 302-308] і має власний рецептор. Для реалізації ефектів FGF23 на органи необхідний білок Клото [4], що представляє собою $\beta$-глюкозидазу, яка приєднується до рецептора FGF23 і С-терміналу цього гормону, тим самим конвертуючи канонічні рецептори FGF23 в специфічні. Білок Клото $\epsilon$ трансмембраним протеїном, який крім інших ефектів, забезпечує певною мірою чутливість організму до інсуліну і уповільнює процес старіння в дослідах на тваринах. FGF23 має фосфатурічний ефект, стимулює секрецію ПТГ і гальмує $1 \alpha$-гідроксилазну активність нирок, призводячи до зниження синтезу КТ і його рівня в сироватці крові [4].

Кальцитонін справляє значно менший вплив на Са-Р обмін. Цей пептидний гормон, що складається з 32 амінокислот, секретується C-клітинами щитоподібних залоз. Стимулом для збільшення секреції є підвищення концентрації Ca2+ в плазмі крові. Гормон має гіпокальціємічну дію за рахунок пригнічення активності і формування остеокластів (зменшення кісткової резорбції), а також, можливо, за рахунок зниження реабсорбції Сa і Р в нирках і зменшення абсорбції Са в кишківнику. Загальна схема регуляції P-Са обміну показана на рис. 2. Порушення Са-P балансу проявляються зміною рівнів Сa, Р сироватки крові, зміною вмісту гормонів в сироватці крові (ПТГ, КТ, КД), розвитком кісткової патології і ектопічної кальцифікації судин і м'яких тканин.

Корекція гіперфосфатемії низькофосфорною дієтою і застосуванням фосфат-біндерів все частіше визнаються в якості важливого терапевтичного підходу до запобігання небезпечних для життя ускладнень у діалізних хворих. Згідно Клінічних практичних рекомендацій K/DOQI, споживання фосфору слід обмежувати до 8001000 мг/добу (з корекцією на харчову потребу в білку). Якщо, незважаючи на обмеження споживання фосфатів з їжею, не вдається контролювати рівень фосфору і ПТГ в межах цільових значень, необхідно призначати фосфат-біндери [7]. В дослідженні, проведеному на кафедрі пропедевтики внутрішньої медицини № 2 НМУ ім. О.О.Богомольця, вміст кальцію, фосфору та паратгормону сироватки крові визначали у пацієнтів з XXН до початку лікування та впродовж 6 місяців на тлі гіпофосфатної дієти, використання фосфат-біндерів та активних форм вітаміну D3. Якщо у пацієнта вихідний рівень фосфатемії перевищував цільовий рівень, призначали дієту з обмеженням добового вмісту фосфору у продуктах харчування денного раціону до 800-1000 мг. У більшості хворих на XXН 3-4 стадій вдалось досягти корекції фосфатемії за допомогою дієти, а при 5 стадії XXН однієї дієтотерапії недостатньо. Для корекції фосфатемії у таких пацієнтів призначали кальціймісткий фосфат-біндер - кальція карбонат 1,0-1,5 г/добу. Призначення кальцитріолу або $\alpha$-кальцидолу проводилось під щомісячним контролем рівнів кальцію та фосфору сироватки крові, тому що при підвищенні рівня кальцію вище 2,37 ммоль/л і рівня фосфору вище 1,49 ммоль/л, необхідно припинити прийом препаратів вітаміну D до нормалізації зазначених показників. Початкова доза кальцитріолу та $\alpha$-кальцидолу у пацієнтів на XXН 3-4 стадій становила 0,25 мкг/добу. Було зроблено висновок, що на тлі комплексного лікування відбулось покращення клініко-лабораторних показників: зменшення проявів судомного синдрому, парестезій, зуду шкіри, у частини хворих досягнуто цільових рівнів фосфору, кальцію та паратгормону. Отже, комплексне лікування хворих на ХХH 3-5 стадій повинно передбачати діагностику та корекцію порушень фосфорно-кальцієвого обміну [8]. В якості фосфат-біндерів найбільш часто використовують кальцію карбонат і кальцію ацетат [11]. Однак, тривалий прийом фосфат-зв'язуючих препаратів на основі солей кальцію може викликати гіперкальціємію, яка на тлі прийому кальцію карбонату буває в 3,5 рази частіше, ніж при використанні кальцію ацетату [11].

Фосфат-біндери на основі кальцію ефективно знижують концентрацію фосфору в сироватці та можуть використовуватися в якості початкової фосфат-зв'язуючої терапії. При цьому сумарна доза елементарного кальцію, котрий використовується для зв'язування фосфору, що надходить з їжею, не повинна перевищувати 1,5 г/добу [9]. Фосфат-біндери на основі кальцію не повинні застосовуватися у діалізних хворих з гіперкальціємією (коректований загальний кальцій сироватки вище 2,54 ммоль/л) і в тих випадках, коли рівень ПТГ плазми нижче 150 пг/мл (16,5 ммоль/л) при 2 послідовних вимірах [10]. У таких хворих слід віддавати перевагу фосфат-біндерам, що не містять кальцій

У деяких пацієнтів, що тривалий час отримують лікування гемодіалізом, в ряді випадків не вдається досягти оптимальної корекції фосфорно-кальцієвого обміну, що може призводити до прогресування вторинного гіперпаратиреозу, його переходу в третинний гіперпаратиреоз. Так, у дослідженні, проведеному на кафедрі внутрішньої медицини № 3 ТДМУ імені І.Я. Горбачевського, у хворих на XXH спостерігалися порушення мінерального обміну у вигляді гіпокальціємії та гіперфосфатемії, підвищення рівня Са $\mathrm{P}$ продукту, які поглиблювалися при прогресуванні ХНН. У більшості пацієнтів спостерігалася дисфункція паращитоподібних залоз, що зумовлювало висо- 
ку частоту кісткової патології у даного контингенту хворих. У пацієнтів на додіалізних етапах XXH переважав ВГПТ (у 76\% осіб). Для пацієнтів на гемодіалізі поряд із гіперпаратиреозом, який виникав у 54\% осіб, характерним був відносний гіпопаратиреоз - у 33\% хворих. Ступінь вираженості ВГПТ зростала зі стадією XXН та поглиблювалася під час лікування гемодіалізом [11]. У подібних випадках розглядається питання про паратиреоїдектомію. Показання до паратиреоїдектомії можуть виникнути при рівні паратгормону більше 800 пг/мл, вираженої остеодистрофії, остеомаляції, гіперкальціємії та гіперфосфатемії, резистентної до лікування. Методом вибору $€$ субтотальна паратиреоїдектомія або тотальна паратиреоїдектомія з аутотрансплантацією тканини паращитоподібної залози [10].

Відповідно до клінічних рекомендацій NKFKDOQITM (Ініціатива щодо поліпшення якості лікування захворювань нирок Національного ниркового фонду США), головною метою терапії $€$ досягнення цільових рівнів основних показників фосфорно-кальцієвого обміну: рівня ПТГ - 150300 пг/мл, скоригованого загального кальцію (Са) - 2,1-2,37 ммоль/л, фосфору (P) - 1,13-1,78 ммоль/л і кальцій-фосфорного продукту (Ca*P) $<4,44$ ммоль2/л2 [10].

Адекватний контроль за чотирма основними біохімічними показниками кісткового і мінерального обміну залишається однією з найбільш складних задач, вирішити яку вдається у менш ніж 6\% діалізних хворих [12]. У численних клінічних дослідженнях показано, що серед хворих, які досягли цільових значень за рівнями ПТГ, Са і $P$, ризик смерті виявляється значно нижчим [13].

Як вже зазначалося, серцево-судинні ускладнення $€$ основною клінічною проблемою у пацієнтів із хронічною хворобою нирок та кінцевою стадією ниркової недостатності; рівень серцевої смертності становить приблизно 40-50\% усіх смертей у цих пацієнтів. Високий рівень інфаркту міокарда також неодноразово був зафіксований саме у пацієнтів із ХХH [14]. Це викликає особливий інтерес, оскільки виявлено, що поширеність коронарної атероми у пацієнтів із XXH становила приблизно 30\% при дослідженнях аутопсії та коронарної ангіографії. Таким чином, коронарні фактори, тобто атеросклероз, і некоронарні фактори можуть відігравати важливу роль у ґенезі серцевих ускладнень у хворих на ХХН. Крім того, ниркова недостатність останнім часом також визначається як предиктор смертності на різних стадіях периферичних судинних захворювань. Зокрема, зафіксовані помітні відмінності в патогенезі, морфології та перебігу атеросклерозу та артеріосклерозу в умовах ниркової недостатності. Серед інших, у клінічних та аутопсійних дослідженнях було виявлено збільшення утворення бляшок та особливо значну інтенсивність каль- цифікації судин [15]. Окрім так званих класичних чи традиційних факторів ризику, важлива роль для некласичних факторів ризику, таких як мікрозапалення, гіперфосфатемія та окислювальний стрес, була задокументована у пацієнтів 3 нирковою недостатністю та детально обговорюється [15].

Фактор росту фібробластів 23 (FGF23) є визначальним предиктором порушень метаболізму мінеральних речовин і постає як можливий фактор ризику, що лежить в основі серцево-судинних порушень у хворих на XXН. Однак його вплив у осіб, які не страждають на XXH, менш зрозумілий. Нещодавно проведене перехресне дослідження показало зв'язки між рівнем FGF23 та параметрами мінерального обміну та атеросклерозом каротидних судин у популяції з високим серцево-судинним ризиком із збереженою функцією нирок [16]. Навіть при встановленні нормально функціонуючої системи, фосфатFGF23-кальцитріол FGF23 незалежно асоціюється 3 IMT-CC, сурогатом атеросклеротичної судинної дисфункції. Це підтримує уявлення про FGF23 як чинник підвищеного серцево-судинного ризику, незалежного від наявності ниркової недостатності.

При тому, в більш ранньому дослідженні [17] стверджувався низький рівень зв'язку між сироватковим рівнем кальцію та паратиреоїдного гормону й ризиком смерті та серцево-судинних подій при хронічній хворобі нирок. Підкреслювалася роль більш високого рівня фосфору в сироватці крові як чинника смертності в цій популяції.

У дослідженні Dzgoeva FU (2011) з'ясовували механізми розвитку гіпертрофії лівого шлуночка та можливого кардіопротективного впливу корекції анемії у пацієнтів із кінцевою стадією ниркової хвороби [18]. Пацієнтів обстежували клінічно з оцінкою рівнів паратгормону, кальцію, фосфору, еритроцитарних показників, феритину в сироватці крові, трансферину крові. Терапія була спрямована на корекцію анемії, артеріальної гіпертензії, фосфорно-кальцієвого обміну. Після 18 місяців спостереження та лікування препаратами еритропоетину та заліза, інгібіторами АПФ, блокаторами рецепторів ангіотензину II, бета-адреноблокаторами, препаратами, що регулюють фосфорно-кальцієвий обмін, у деяких випадках спостерігалось зниження систолічного артеріального тиску, досягнення цільового рівня гемоглобіну, регресія LVH. Зроблено висновок, що комбіноване лікування хворих на гемодіалізі, включаючи антианемічні, антигіпертензивні препарати, сприяло поліпшенню LVH або його регресу в деяких випадках.

Поліпшення розуміння нетрадиційних факторів ризику, у тому числі тих, які $є$ на ранніх етапах XXH, може призвести до нових терапевтичних стратегій. Було показано, що XXH $€$ незалежним 
фактором ризику серцево-судинних захворювань у широкій популяції, але бракує даних про пов'язані з цим потенційні відхилення, що виникають у поєднанні зі зниженою ШКФ, що може сприяти підвищенню ризику. Накопичуються дані щодо ролі відхилень кальцію, фосфору, вітаміну D та ПТГ у розвитку серцево-судинних захворювань. При цьому відмічено, що дефіцит вітаміну D присутній навіть на ранніх стадіях XXH. У світлі останніх спостережних досліджень, що показують асоціацію терапії вітаміном D та підвищення виживаності гемодіалізних пацієнтів, вплив вітаміну D на серцево-судинну систему набув серйозної дискусії.

За даними проведеного аналізу, [19] три механізми можуть бути важливими для захисного впливу вітаміну D при серцево-судинних захворюваннях: вітамін D може пригнічувати різні аспекти запалення, які були встановлені як ключовий патогенетичний механізм при атеросклерозі; вітамін D чинить антипроліферативну дію на гіпертрофію та проліферацію клітин міокарда, що лежить в основі патогенезу застійної серцевої недостатності; вітамін D діє як негативний ендокринний регулятор для системи ренін-ангіотензину, який само по собі відіграє важливу роль у розвитку гіпертонії та функціональному стані серцево-судинної системи загалом. На основі огляду доказів як із фундаментальних наукових, так і з клінічних досліджень, доведено, що дефіцит вітаміну D може бути некласичним фактором ризику серцево-судинних захворювань при XXН.

Висновки. Резюмуючи огляд літератури, присвячений аналізу порушень фосфорно-кальцієвого обміну у пацієнтів із XXH і серцево-судинними захворюваннями та основних методів його корекції, безліч нових фактів підтверджують, що підвищення рівнів FGF23 і ПТГ $є$ відповідальним за несприятливі ефекти надмірного вмісту фосфатів, але інгібування цих компенсаційних механізмів клінічно неможливо, тому що це призводить до небезпечних змін в мінеральному обміні. При цьому, профілактика кардіоваскулярних ускладнень у осіб з порушеннями в системі FGF23/Klotho повинна включати корекцію вмісту фосфатів, так як їх атерогенну роль продемонстровано, а спроби зменшити абсорбцію фосфатів з використанням тільки фосфат-біндерів можуть результувати збільшенням абсорбції фосфатів в той час, коли фосфат-біндери не присутні в порожнині кишківника. Можливим терапевтичним підходом також $є$ контроль дієти таких пацієнтів за рівнем Ca, P та вітаміну D з блокадою кишкового активного перенесення фосфатів для зниження дієтичної фосфатної абсорбції.

\section{ЛITEPAТУРА}

1. Hu MC, Shi M, Zhang J, Pastor J, Nakatani T, Lanske B, Razzaque MS, Rosenblatt KP, Baum
MG, Kuro-o M, Moe OW. Klotho: a novel phosphaturic substance acting as an autocrine enzyme in the renal proximal tubule. FASEB J. 2010; 24:3438-3450. [PubMed: 20466874].

2. Silva BC, Costa AG, Cusano NE, Kousteni S, Bilezikian JP. Catabolic and anabolic actions of parathyroid hormone on the skeleton. J.Endocrinol.Invest. 2011; 34:801-810. [PubMed: 21946081.

3. Razzaque MS, St_Arnaud R, Taguchi T, Lanske B. FGF-23, vitamin D and calcification: the unholy triad. Nephrol Dial Transplant 2005; 20 (10): 2032-2035.

4. Torres PU, Prie D, Beck L et al. Klotho gene, phosphocalcic metabolism, and survival in dialysis. J Ren Nutr 2009; 19 (1): 50-56.

5. Golovin Al, Efremova OA, Khodykina YuE. Features of phosphorus-calcium exchange in patients who are protected by program hemodialysis. Research Result. Medicine and Pharmacy. 2016; 2(4): 24-29.

6. Block G.A., Hulbert-Shearon T.E., Levin N.W., Port F.K. Association of serum phosphorus and calcium $x$ phosphorus product with mortality risk in chronic hemodialysis patients: $A$ national study. Am J Kidney Dis 1998. 31. Pp. 607-617.

7. Wang L., Jerosch-Herold M., Jacobs J. et al. Coronary Artery Calcification and Myocardial Perfusion in Asymptomatic Adults: The MESA (Multi-Ethnic Study of Atherosclerosis). J. Am. Coll. Cardiol. 2006. 48. Pp. 1018-1026.

8. Никула ТД, Мойсеєнко ВО, Карпенко ОВ. Корекція порушень фосфорно-кальцієвого обміну у хворих на хронічні хвороби нирок. Видавництво СумДУ, 2011.

9. Craver L., Marco M.P., Martinez I. et al. Mineral metabolism parameters throughout chronic kidney disease stages 1-5-achievement of K/ DOQI target ranges. Nephrol. Dial. Transplant. 2007. 22. Pp. 1171-1176.

10. National Kidney Foundation: Clinical practice guidelines for chronic kidney disease: Evaluation, classification and stratification / Am. J. Kidney Dis. - 2002. - Vol. 39, Suppl. 1. - P. 1-26. 5.

11. Мартинюк Л.П., Мартинюк Л.П., Ружицька О.О. Особливості мінерального обміну та функції паращитоподібних залоз при хронічній хворобі нирок. Журнал «Боль. Суставы. Позвоночник» 2 (06) 2012.

12. Tan AU Jr., Levine B.S., Mazess R.B. et al. Effective suppression of parathyroid hormone by 1 alpha-hydroxy-vitamin D2 in hemodialysis patients with moderate to severe secondary hyperparathyroidism. Kidney Int. 1997. 51. Pp. 317-323. 
13. Danese M., Belozeroff V., Smirnakis K. et al. Consistent control of mineral and bone disorder in incident hemodialysis patients. Clin. J. Am. Soc. Nephrol. 2008. 3. Pp. 1423-1429.

14. Foley, R.N.; Parfrey, P.S.; Harnett, J.D.; Kent, G.M.; Murray, D.C.; Barre P.E. Impact of Hypertension on Cardiomyopathy, Morbidity and Mortality in End-Stage Renal Disease. Kidney Int. 1996, 49, 1379-1385.

15. London, G.M.; Marchais, S.J.; Guerin, A.P.; Metivier, F.; Pannier, B. Cardiac Hypertrophy and Arterial Alterations in End-Stage Renal Disease: Hemodynamic Factors. Kidney Int. 1993, 43 (suppl. 41), S42-S49.

16. Rodríguez-Ortiz ME, Alcalá-Díaz JF, Canalejo $A$, Torres-Peña JD, Gómez-Delgado F, MuñozCastañeda JR, Delgado-Lista J, Rodríguez $M$, López-Miranda J, Almadén Y Fibroblast growth factor 23 predicts carotid atherosclerosis in individuals without kidney disease. The CORDIOPREV study. Eur J Intern Med. 2019 doi: 10.1016/j.ejim.2019.12.008.

17. Suetonia C. Palmer; Andrew Hayen; Petra Macaskill et al. Fabio Pellegrini; Jonathan C. Craig; Grahame J. Elder; Giovanni F. M. Strippoli. Serum Levels of Phosphorus, Parathyroid Hormone, and Calcium and Risks of Death and Cardiovascular Disease in Individuals With Chronic Kidney Disease. A Systematic Review and Meta-analysis. JAMA. 2011;305(11):1119-1127. doi:10.1001/ jama.2011.308.

18. Dzgoeva FU, Gatagonova TM, Kadzaeva ZK, Khamitsaeva OV, Kochisova ZKh, Dzutseva $A T$, Bazaeva BG. Left ventricular hypertrophy in end-stage renal disease and its possible regression as a result of correction of anemia and arterial hypertension. Ter Arkh. 2011; 83(6):42-6.

19. Adeera LevinY.A.N. ChunLi Vitamin $D$ and its analogs: Do they protect against cardiovascular disease in patients with kidney disease? Kidney International Volume 68, Issue 5, November 2005, Pages 1973-1981.

\section{PEЗЮME}

\section{ГОРМОНАЛЬНАЯ РЕГУЛЯЦИЯ СА-Р ОБМЕНА У ПАЦИЕНТОВ С ХРОНИЧЕСКОЙ БОЛЕЗНЬЮ ПОЧЕК И ТЕРАПЕВТИЧЕСКИЕ ПОДХОДЫ К КОРРЕКЦИИ}

Мойсеенко В.А., Медведев Т.Н.

Национальный медицинский университет имени А.А. Богомольца (Киев, Украина)

Введение. Одной из наиболее частых и тяжелых проблем, возникающих при лечении диализных больных, является коррекция фосфорно-кальциевого обмена. При хронической почечной недостаточности нарушаются все звенья фосфорно-кальциевого обмена. При снижении скорости клубочковой фильтрации
(СКФ) ниже 60 мл/мин/1,73 м² уменьшается фильтрация фосфора и повышается его концентрация в сыворотке крови, что вызывает повышение секреции паратиреоидного гормона (ПТГ).

Цель. Обобщить сведения о роли гормональной регуляции фосфорно-кальциевого обмена в патогенезе развития хронической болезни почек и сердечнососудистых заболеваний, которые её сопровождают, и проанализировать основные терапевтические подходы для корекции этих нарушений.

Материалы и методы. Библиографический - проведен теоретический анализ и осуществлено обобщение данных литературы, проанализировано фактическое содержание. При исследовании использованы анкетно-опросный метод, а также - описание, анализ, реферирование.

Результаты и их обсуждение. ПТГ производится главными клетками паращитовидных желез (ПЩЖ). Концентрация Са2 + в сыворотке крови является основным модулятором секреции ПТГ [2]. Стимуляция кальций-чувствительных рецепторов (КЧР) ПЩЖ через каскад реакций приводит в итоге к подавлению секреции ПТГ. Дополнительным стимулом увеличения секреции ПТГ является гиперфосфатемия. ПТГ имеет следующие физиологические эффекты: стимулирует резорбцию кальция из костной ткани, реабсорбцию кальция в почечных канальцах. Витамин $D\left(D_{3}\right.$ и $\left.D_{2}\right)$ в ассоциации с витамин D-связывающим белком переносится в печень, где гидроксилируется с образованием $25(\mathrm{OH})$ D или кальцидиол (KD), который в дальнейшем подвергается $1 \alpha$-гидроксилированию в почечных канальцах, превращаясь в активную форму витамина D - кальцитриол (KT) или D-гормон. Белок Клото является трансмембранным протеином, который помимо прочих эффектов, обеспечивает в определенной степени чувствительность организма к инсулину и замедляет процесс старения в опытах на животных. FGF23 имеет фосфатурический эффект, стимулирует секрецию ПТГ и тормозит $1 \alpha$-гидроксилазную активность почек, приводя к снижению синтеза КТ и его уровня в сыворотке крови.

Выводы. Повышение уровня FGF23 и ПТГ является ответственным за неблагоприятные эффекты избыточного содержания фосфатов, но ингибирование этих компенсационных механизмов клинически невозможно, так как это приводит к опасным изменениям в минеральном обмене. При этом, профилактика кардиоваскулярных осложнений у лиц с нарушениями в системе FGF23/Klotho должна включать коррекцию содержания фосфатов, так как их атерогенную роль продемонстрировано, а попытки уменьшить абсорбцию фосфатов с использованием только фосфатбиндеров могут привести к увеличению абсорбции фосфатов в то время, когда фосфат-биндеры не присутствуют в полости кишечника. Возможно, одним из терапевтических подходов у таких пациентов есть диетический контроль за уровнями $\mathrm{Ca}, \mathrm{P}$ и витамина D с блокадой кишечного активного переноса фосфатов для снижения диетической фосфатной абсорбции.

Ключевые слова: фосфорно-кальциевый обмен, хроническая болезнь почек, сердечно-сосудистые расстройства. 


\section{SUMMARY}

\section{HORMONAL REGULATION OF SA-P EXCHANGE IN PATIENTS WITH CHRONIC KIDNEY DISEASE AND THERAPEUTIC APPROACHES TO CORRECTION}

\author{
Moyseyenko V.O., Medvedyev T.M.
}

Bogomolets National Medical University (Kyiv, Ukraine)

Introduction. One of the most frequent and difficult problems arising in the treatment of dialysis patients is the correction of phosphorus-calcium metabolism. In chronic renal failure, all links of phosphorus-calcium metabolism are disrupted. With a decrease in the glomerular filtration rate (GFR) below $60 \mathrm{ml} / \mathrm{min} / 1.73 \mathrm{~m}^{2}$, the filtration of phosphorus decreases and its concentration in the blood serum increases, which causes an increase in the secretion of parathyroid hormone (PTH).

Goal. To summarize the information about the role of hormonal regulation of phosphorus-calcium metabolism in the pathogenesis of chronic kidney disease and cardiovascular diseases, it is accompanied, and to analyze the main therapeutic approaches for the correction of these disorders.

Materials and methods. Bibliographic - a theoretical analysis is carried out and a generalization of literature data is carried out, the actual content is analyzed. In the study, a questionnaire-survey method was used, as well as description, analysis, abstracting.

Results and discussion. PTH is produced by the main cells of the parathyroid glands (PTH). Serum Ca2 + concentration is the main modulator of PTH secretion [2]. Stimulation of the calcium-sensitive receptors (CSR) of the thyroid gland through a cascade of reactions ultimately leads to the suppression of PTH secretion. An additional stimulus for an increase in PTH secretion is hyperphosphatemia. PTH has the following physiological effects: stimulates the resorption of calcium from bone tissue, reabsorption of calcium in the renal tubules. Vitamin $D\left(D_{3}\right.$ and $\left.D_{2}\right)$, in association with vitamin D-binding protein, is transported to the liver, where it is hydroxylated to form $25(\mathrm{OH}) \mathrm{D}$ or calcidiol $(\mathrm{KD})$, which then undergoes $1 \alpha$-hydroxylation in the renal tubules, turning into the active form of the vitamin $\mathrm{D}$ is calcitriol (KT) or D-hormone. Protein Klotho is a transmembrane protein that, among other effects, provides some degree of insulin sensitivity and slows down the aging process in animal experiments. FGF23 has a phosphaturic effect, stimulates the secretion of PTH and inhibits the $1 \alpha$-hydroxylase activity of the kidneys, leading to a decrease in the synthesis of QD and its level in the blood serum.

Conclusions. Elevated FGF23 and PTH levels are responsible for the adverse effects of excess phosphate, but inhibition of these compensatory mechanisms is clinically impossible as it leads to dangerous changes in mineral metabolism. At the same time, the prevention of cardiovascular complications in persons with disorders in the FGF23/Klotho system should include correction of the phosphate content, since their atherogenic role has been demonstrated, and attempts to reduce the absorption of phosphates using only phosphate binders can lead to an increase in the absorption of phosphates at a time when phosphate binders are not present in the intestinal cavity. Possibly one therapeutic approach in these patients is dietary control of $\mathrm{Ca}, \mathrm{P}$ and vitamin $\mathrm{D}$ levels with blockade of intestinal active phosphate transport to reduce dietary phosphate absorption.

Key words: phosphorus-calcium metabolism, chronic kidney disease, cardiovascular disorders.

\section{АВТОРСЬКА ДОВІДКА}

\author{
Мойсеєнко Валентина Олексіївна \\ Національний медичний університет \\ імені О.О. Богомольця, академік НАН ВО України, \\ д.м.н., професор \\ моб.: +380677779249 \\ E-mail: moyseyenko_vo@ukr.net
}

\section{Мойсеенко Валентина Алексеевна}

Национальный медицинский университет имени А.А. Богомольца, академик НАН ВО Украины, д.М.Н., профессор,

моб .. +380677779249

E-mail: moyseyenko_vo@ukr.net

\section{Moyseyenko Valentyna}

Bogomolets National Medical University, MD, PhD, Professor , Academician of the National Academy of Sciences of Ukraine

mob .: +380677779249

E-mail: moyseyenko_vo@ukr.net

\section{Медведєв Тарас Миколайович}

Національний медичний університет імені О.О. Богомольця, дослідник

Адреса: бул. Т. Шевченка, 13, Київ, Україна

моб.: +380689964177

E-mail: taras.allo2020@gmail.com

\section{Медведев Тарас Николаевич}

Национальный медицинский университет имени А.А. Богомольца, исследователь

Адрес: бул. Т. Шевченко, 13, Киев, Украина

моб .: +380689964177

E-mail: taras.allo2020@gmail.com

\section{Medvedyev Taras}

Bogomolets National Medical University, researcher Address: blvd. T. Shevchenko, 13, Kyiv, Ukraine моб : +380689964177

E-mail: taras.allo2020@gmail.com 